\title{
Forensic Examination of Soil Samples from the Point of View of Physico-Chemical Expertise
}

\author{
Georgiana Mardare (Bălușescu) ${ }^{1}$, Nicoleta-Elena Hegheș ${ }^{2}$ \\ I"Gheorghe Asachi" Technical University of Iaşi, Iași, Romania, georgiana.balusescu@tuiasi.ro \\ 2"Dimitrie Cantemir" Christian University of Bucharest, Bucharest, Romania,nicoleta.heghes@ucdc.ro
}

\begin{abstract}
The potential of forensic expertise in the analysis of soil samples has been recognized for a century now, but over the last 20 years, these types of evidence have been much more widely used both as an investigative tool and as evidence in court. Forensic Chemistry is at the crossroads of science with the law, being a discipline apart from its applicability to the judiciary. Samples are obtained from various objects and often contain only very small amounts of chemicals. Most of the time, the sample harvested on the spot is no longer sampled, but it is actually the sample to be analyzed. This is also the condition of aggregation of the sample, the homogeneity of the sample/matrix or the compounds sought. Sometimes, however, even the evidence can be considered chemically homogeneous, and then representative samples (paints, textiles, plastics, etc.) can be sampled. The rest of the materials are heterogeneous (soil, building materials, fire residues, etc.). The extremely rapid evolution of science in recent years has resulted in the development of new, powerful and performing technologies. This evolution and the refinement of analytical tools make it possible at present to perform forensic investigations at the smallest scale of dimensions, with greater sensitivity and with great differentiation intervals. At the same time it is possible to discover unpredictable or previously inaccessible samples.
\end{abstract}

KEYWORDS: chromatography, forensic expertise, samples, spectrometry, trace soil

\section{Introduction}

Soil is a part of the upper layer of the Earth's crust, consisting of a complex mixture of minerals, decomposing organisms, water and air, and a variety of chemical, mineralogical, biological and physical properties. Pedology is the science that deals with the study of the control and improvement of soil properties. Pedology deals with both paedogenesis, morphology, classification and the study of physical, chemical, biological and mineralogical properties of soils. Pedology also investigates the correlation between the laws underlying the formation, evolution, geographical distribution, classification and soil fertility (Seceleanu 2008, 4-10).

Morphological soil interpretation provides a quick, non-destructive visual approach to examine and distinguish between several types of soil samples in criminological expertise. This is why all samples are characterized primarily by morphological descriptors:

1) Colour of the soil matrix and segregation;

2) Soil oxidation reactions;

3) Texture;

4) Form of granules;

5) Structure, type, quality, and size;

6) Consistency;

7) Segregation and coarse fragmentation;

8) Roots and pores;

9) Water retention;

10) Effervescent reactions, etc.

A full, visual description of the soil is essential because it serves as a basis for soil identification, classification, correlation, mapping and interpretation. This is particularly the case where the land in question was transported by a vehicle, footwear or shovel.

Also, in analysing different layers of soil or horizons with different properties, it is recommended that the forensic expertise of the soil be analysed in each layer. Of particular importance are the morphological characteristics of the soil. 
In most cases, the classification or assessment of a soil requires information on the chemical composition. Forensic experts can often estimate to a certain extent the composition of soils by simply visual and physical examination. They can determine the content of organic substances in soil material, iron content, saturation degree, can determine if it is sand/mud/clay, components that can be determined due to colour and texture. Other sensory indices, including the overall horizon structure, vegetation and topography, can be determined and information about the probable composition of a soil can be provided. This produces promising results, although it is usually still based on sample preparation, transport and laboratory analysis (Aitkenhead et al. 2012, 108).

Forensic Chemistry, as an integral part of forensics, is the one that, through the chemical expertise of the following matter left on the spot, handles relevant, decisive evidence to document criminal and civil cases. Physico-chemical expertise in most cases refers to examinations and analyses of elements or features of objects related to the circumstances of the offense, especially those directly related to the results of the examination, the basic objective of physico-chemical expertise determining the nature of the evidence raised during the investigation of the place of deed and their comparative examination in the context of establishing the legal truth. In the criminological investigation of a wide variety of cases, the chemist expert has an important role to play by examining and analysing the evidence available, able to produce pertinent conclusions demonstrating the power of science in completing the idea of justice, creating maximum opportunities for a fair and equitable solution of all judicial cases (Stoian and Galan, 111).

\section{Soil composition}

Soil is a complex mixture of minerals, decomposition organisms, water and air, with a variety of chemical, mineralogical, biological and physical properties.

Soil texture describes the size of mineral particles. There are three large sizes of soil particles: sand, sludge and clay. Sand describes the largest particle size and the smallest particle size. There are also three subcategories of soil - clay soil, peat soil and limestone soil (Table 1).

Table 1. Subcategories of Type Soil (Bertino 2012, 341)

\begin{tabular}{|c|c|c|c|c|c|}
\hline $\begin{array}{l}\text { Soil } \\
\text { Type }\end{array}$ & Feel & Composed of & Location & $\begin{array}{c}\text { Other } \\
\text { Characteristics }\end{array}$ & \\
\hline Sand & gritty & $\begin{array}{l}\text { Weathered } \\
\text { rock }\end{array}$ & $\begin{array}{l}\text { deserts, } \\
\text { beaches, } \\
\text { riverbeds }\end{array}$ & $\begin{array}{l}\text { large visible } \\
\text { particles, loses } \\
\text { water quickly }\end{array}$ & \\
\hline Clay & sticky & $\begin{array}{c}\text { small } \\
\text { particles } \\
\text { adhering to } \\
\text { each other }\end{array}$ & various & $\begin{array}{l}\text { small particles, } \\
\text { clumps, poor } \\
\text { drainage }\end{array}$ & \\
\hline Silt & $\begin{array}{l}\text { crumbly, } \\
\text { slippery } \\
\text { like flour }\end{array}$ & $\begin{array}{l}\text { medium- } \\
\text { sized mineral } \\
\text { particles }\end{array}$ & $\begin{array}{l}\text { sediment in } \\
\text { riverbeds }\end{array}$ & $\begin{array}{l}\text { good drainage, } \\
\text { easily farmed }\end{array}$ & \\
\hline Peat & $\begin{array}{c}\text { compressib } \\
\text { le }\end{array}$ & $\begin{array}{l}\text { decaying } \\
\text { organic } \\
\text { material }\end{array}$ & $\begin{array}{l}\text { bogs, areas } \\
\text { where water is } \\
\text { retained by } \\
\text { organic matter } \\
\text { failing to } \\
\text { decompose }\end{array}$ & $\begin{array}{l}\text { acidic, used with } \\
\text { other soil types in } \\
\text { fertilizer because of } \\
\text { its ability to retain } \\
\text { water }\end{array}$ & \\
\hline
\end{tabular}




\begin{tabular}{|c|c|c|c|c|c|}
\hline Loam & loose & $\begin{array}{c}\text { sand, silt, and } \\
\text { clay mixture }\end{array}$ & various & $\begin{array}{c}\text { best soil for } \\
\text { agriculture }\end{array}$ & alkaline \\
Chalk & brown & $\begin{array}{c}\text { with mineral } \\
\text { stones }\end{array}$ & $\begin{array}{c}\text { poor for } \\
\text { below the top } \\
\text { soil } \\
\text { requires the } \\
\text { addition of } \\
\text { fertilizer and } \\
\text { humus }\end{array}$ & \\
\hline
\end{tabular}

The clay soil is a light-brown soil type and is sticky when wet. In these soils we encounter metal oxides (primary minerals in rock) and quartz (secondary minerals), clay minerals. Clay minerals are of particular importance for soil. They are able to retain, provide ions involved in nutrition, such as calcium, potassium, magnesium. Together with mineral particles, the soil may also contain organic matter, such as plants and decomposing animals.

Soil containing $20 \%$ more organic decomposing materials is called peat soil (Turbot is an accumulation of organic matter consisting of leaves, grass, mushrooms or decomposed insects). It is acidic and wet.

\section{Physico-chemical forensic expertise aspects of soil samples}

The principle of E. Locard's transfer postulates that traces of both physical and biological nature can be found at the scene of the crime, because the perpetrator always leaves something behind him in direct contact with the victim and/or the objects in that area, in a similar manner, the perpetrator will take with him fragments of a material nature, which can be found on his clothing, on motor vehicles or on certain objects. These traces are often found in infinitesimal quantities, "micrograms", which can be emphasized only by appropriate methods of physical-chemical analysis. (Alămoreanu, 2013).

Traces and micro-traces abound on-site in most cases and can be used as chemical samples in a rich casuistry. In the forensic sense, any contact, no matter how easy, will leave a trace; traces of what remains material, visible or invisible, at the crime scene from the person of the perpetrator, from his clothing or footwear, from the vehicles, weapons, tools or materials he has used, objects or fragments of objects any kind, abandoned or lost by the offender at the place of deed, as well as all that could be materially attached, visible or invisible from the crime scene to him. The traces are the result of contact between two surfaces, such as the carpet or floor shoes, or the garments with the upholstered furniture on which the offender has been seated or touched (Stoian 2013, 10).

In forensics, especially comparative examination of traces and micro-traces is of particular importance in determining the circumstances in which crimes have occurred and involves a series of morphological and analytical analyses. The extremely rapid evolution of science in recent years has resulted in the development of new, powerful and performing technologies. This evolution and the refinement of analytical tools make it possible at present to perform forensic investigations at the smallest scale of dimensions, with greater sensitivity and with great differentiation intervals. At the same time it is possible to discover unpredictable or previously inaccessible samples.

The multitude of available analytical equipment makes it easy to obtain certain conclusions by making a greater number of determinations on a single sample.

The soil examination procedure will depend on the amount of sample available. Comparative visual examination of suspicious soil samples with the comparative ones (colours and microstructures) will quickly determine their similarity or non-assimilation. However, before performing colour comparisons, it is necessary for the soil samples examined to be completely dried so that the soils appear darker than the dry soils. 
The following analytical methods and techniques are used to analyse soil samples:

1) Microscopic examinations;

2) Thin layer chromatography (TLC);

3) Spectrometric analysis;

4) Inductively coupled plasma atomic emission spectroscopy (ICP-AES) and inductively coupled plasma mass spectrometry (ICP-MS) analysis.

\section{Microscopic examinations}

Because of similar inorganic composition of soils - generally silicates mixed with carbonates, ubiquitously, soils differentiation from different locations is facilitated by the presence of various highly individualized impurities. It should be noted that the litigation in question must be in sufficient quantity to build a representative soil matrix in order to perform comparative examinations/analyses. Also, for conclusive analyses in such cases, the fine and very fine features coming from the ground with which the support was in contact can only be compared with those of the same size particles. Lower microscopic examination will highlight the content of plant residue, animal residue and fragments of various man-made materials, and with greater increase will highlight the soil's mineral content. If the litigation sample consists of micrograms, only large-scale microscopy will be the main means of comparison (Stoian 2013, 297).

\section{Thin layer chromatography (TLC)}

This method highlights the humus (the organic soil component). Since humus is the result of the decomposition of plants and microorganisms, in humic substances there is a complex mixture of organic substances with different molecular structures characteristic of each phenotype, the soils being different and depending on the quantity and quality of the humus. Organic matter has a major influence on soil aggregation, nutrient reserve and availability, moisture retention and biological activity. Humus influences a range of physical and physicochemical properties of soil: colour, temperature, water capacity, structure, porosity, reaction, $\mathrm{pH}$, adsorption capacity, etc. In the forensic interest, however, the qualitative analysis of humus is not of particular relevance, instead, by calcination the soil samples the quantity of all organic and inorganic soil substances is determined and relevant in the comparative analysis of soils (Stoian 2013, 297 and 298).

\section{Spectrometric analysis}

After examining the naked eye and stereomicroscopes of soil approvals for comparative determination/examination of colour, microstructure and impurities, spectrometric methods are basic tools for establishing the similarities or differences (Stoian 2013, 298 and 299).

\section{Infrared Spectrometry (FTIR)}

FTIR provides information on organic and inorganic soil components (carbonates, silicates). Patterns taken from samples are analysed on a spectrometer by absorbance, transmittance or reflectivity

\section{X-Ray Fluorescence Spectrometry (XRF)}

$\mathrm{X}$-ray fluorescence spectra provide qualitative and quantitative information on elemental soil composition. The analysis is non-destructive.

\section{Analysis with scanning electron microscope (SEM)}

It is addressed in the case where the soil impurity dimensions are below the optical resolution limit of the optical microscope. The method provides information on the morphological appearance of highlighted micro particles as well as qualitative and quantitative inorganic composite information by using energy dispersion (EDS) and wavelength (WDS) x-ray spectrometers. 


\section{Inductively coupled plasma atomic emission spectroscopy (ICP-AES) and inductively coupled plasma mass spectrometry (ICP-MS) analysis}

This analysis allow for the determination of about 50 elements from small clusters. For most elements, the accuracy of ICP measurement is good, but there may be a degree of variation due to sub-sampling procedures, selective material transfer mechanisms, and the grease of spatial variation in existence. If the amount of soil sample is large enough, several fractions of different sizes may be tested, but usually a $150 \mathrm{~mm}$ standard fraction split from a global curve provides sufficient discrimination between the samples and is the most practical means of screening the samples.

\section{GC-MS Analysis}

Is addressed if it is desired to establish the nature of any traces of oil products, bitumen mineral oils, gasoline, diesel, etc. or traces of pesticides, waste, etc. in suspended solids.

\section{Conclusions}

At present, the evolution and refinement of analytical tools makes it possible to conduct forensic investigations at the smallest scale of dimensions, with great sensitivity and with great differentiation intervals. Therefore, it is now possible to discover samples that are impossible to detect or previously inaccessible, and the microurm analysis has become a reality. Performing judicial experiments is necessary as an integral part of the comparative examination. Results are thus obtained which lead to the link between the high-level evidence from the site or the suspects concerned and the comparison ones. The two components of forensic expertise, namely: research (remote sensing, mapping, geophysics, archeology) and sampling / analysis (soil and mineralogical and geochemical sediments) both rely on understanding and evolution of the landscape.

\section{References}

Aitkenhead, M.J., Coull, M.C., Towers, W., Hudson G., Black, H.I.J. 2012. "Predicting Soil Chemical Composition and Other Soil Parameters from Field Observations Using a Neural Network." Computers and Electronics in Agriculture 82: 108-116.

Alamoreanu, Sorin. 2013. Problematica Expertizeor Criminalistice, Note de curs pentru studii de master (Criminal Expertise Issues, Master's Degree Course Notes). Bucharest: Hamangiu Publishing House.

Bertino, J. Anthony. 2012. Forensic Science, Fundamentals \& Investigations. Mason, OH: South-Western Cengage Learning.

Seceleanu, Ion. 2008. "Geografia Solurilor (Soil Geography).” Nature, 4-10.

Stoian, Georgeta Maria and Galan Elena. "Relaţia Microurmă/Întreg stabilită prin metode spectrometrice modern (Relationship Trace Evidence/Entire Physical Evidence Established by Modern Spectrometric Methods and the Formulation of the Conclusions of the Physico-Chemical Expertise Reports)". Revista de Crimonologie, Criminalistică și Penologie: 111, http://old.mpublic.ro/art_doctr_jur.htm.

Stoian, Georgeta Maria. 2013. Contribuția expertizelor fizico-chimice a probelor materiale la probațiunea materială (Contribution of the physical-chemical expertise of the material samples to the material test)." Bucharest: Aktis Tipography. 